\title{
Měsíc norského dramatu v Brně
}

\author{
Klára Škrobánková
}

Festival scénických čteni Specific 2015 - Norsko. 5.-28. května 2015, Brno.

Každý rok v květnu pořádá brněnské nezávislé divadlo Feste Festival scénických čtení Specific, ve kterém si klade za cíl představit současnou dramatickou tvorbu v českém prostředí téměř neznámou. Pro pátý ročník festivalu v květnu 2015 bylo principálem divadla Jiřím Honzírkem a překladatelkami Evou Dohnálkovou a Karolínou Stehlíkovou vybráno šest her autorů severského Norska (Maria Tryti Vennerød, Fredrik Brattberg, Jon Fosse, Finn Iunker, Arne Lygre, Cecilie Løveide). Již volba této skandinávské země ukazuje na změnu směru, jímž se Feste ve své dramaturgii vydává. Všechny předchozí ročníky se věnovaly východním zemím (Bělorusko, Ukrajina, aj.) nebo státům Česku zcela vzdáleným (frankofonní Afrika); Norsko je tak první zemí „vyspělé“ Evropy, s jejíž dramatikou Feste pracuje. Vedle změny geografické se zde divák setkal se změnou pro mnohé jistě vítanou - organizátoři upustili od ideje inscenovat každé ze šesti čtení na jiném místě a soustředili celý festival do areálu bývalé Mosilany na ulici Špitálka. Prostory dnes již nefungujícího textilního závodu tak zároveň poskytly tvůrcům i divákům tu „správnou“ site-specific atmosféru, a publiku navíc odpadla nutnost každý týden bloudit po Brně a hledat neznámé, často i vyloučené lokality, jak tomu bylo v předchozích ročnících. Největším přínosem pátého ročníku však bezpochyby byla úzká spolupráce s Katedrou divadelních studií FF MU. Skupina studentů semináře „Současné skandinávské drama“ pod vedením Karolíny Stehlíkové využila možnosti produkčně se podílet na pořádání festivalu a asistovat osloveným režisérům. Studenti také přišli s nápadem vydávat festivalové noviny, ve kterých by návštěvníkům přibližovali nejen autory her, ale také soubory inscenující jednotlivá čtení či Norsko obecně. V pěti číslech novin Innsikt (norsky „vhled“) mladí teatrologové vedli rozhovory s dramatiky, sami si tyto texty překládali z angličtiny, recenzovali uskutečněná čtení apod.

Festival byl za účasti dramatičky Marie Tryti Vennerød zahájen 5. května 2015 čtením autorčina textu Vic (Meir) v režii Gabriely Krečmerové a Hany Marvanové. Drama o dvou kamarádkách, jejichž nevinné hry skončí smrtí a možná i vraždou jedné z aktérek, vypadalo $\mathrm{v}$ prostorech zaprášené průmyslové budovy snově a naléhavě zároveň. Studenti JAMU ke svému počinu využili potenciál industriální Mosilany na maximum - poprvé a naposled $\mathrm{v}$ tomto ročníku festivalu muselo publikum přecházet za herci pobíhajícími rozlehlými halami a vestoje pak sledovat jednotlivé scény. Ženské postavy v tylových sukních, provazová houpačka zavěšená za kovové trubky na oprýskaném stropě, to vše pak vytvářelo surový kontrast krásy a ošklivosti, reality a iluze, dobra a zla. Témata násilí, odcizenosti dnešní společnosti či viny a neviny, jež se objevila $\mathrm{v}$ prvním inscenovaném 
textu, se pak cyklicky vynořovala při každém následujícím čtení a vytvořila tak ideovou náplň norského Specifiku.

Druhé čtení, také s účastí norského dramatika, připadlo na 10. května. Černou komedii Fredrika Brattberga Návraty (Tilbakekomstene) režíroval Tomáš Sýkora, herec Divadla Husa na provázku. Dvě postavy se v polorozpadlých kulisách rodinného domku (k nimž vhodně posloužila místnost pro kontrolora provozu ve zpustlé Mosilaně) snaží vyrovnat se zmizením a smrtí svého jediného syna. Syn se ale záhy vrací, pak opět mizí a zase se objevuje. Kolotoč návratů tak v ústřední dvojici nevyvolává smutek nebo radost, ale jen otupění a lhostejnost, které jsou podtrženy syrovým interiérem továrny.

Při druhém čtení festivalu se poprvé objevila otázka, která pak v myslích jednotlivých diváků vyvstávala pravidelně jaké jsou hranice žánru scénického čtení? $\mathrm{V}$ mnohých případech herci hráli bez textu, protože inscenované čtení obsahovalo množství akce, při níž byly stránky scénáře v rukou performerů omezující. Některé večery jsou pak pravým opakem - účastníci staticky sedí kolem stolu nebo na lavičce, čtou a občas zvednou oči k publiku. Do této druhé skupiny patří i třetí čtení dnes již klasika moderního norského divadla Jona Fosseho. 14. května se režie jeho díla Podzimni sen (Draum om Hausten) zhostil Vojtěch Bárta z pražského Chemického divadla. Byt šlo o inscenaci uvedenou v propracovaných kostýmech i světelném designu, několik herců nenabídlo hrstce diváků více než jen monotónní čtení hry.

Oproti tomu program ze dne 20. května plně využil průmyslového prostředí labyrintu továrních hal. Čtení divadelního textu Finna Iunkera Answering Machine připravilo uskupení Depresivní děti touží po penězích s režisérem Jakubem Čermákem a vytvořilo $\mathrm{v}$ Mosilaně interaktivní bludiště s množstvím stanovišt’, kde diváci postupně odpovídali na otázky a pak také různé kladli otázky všeho druhu, ty každodenní i filozofické, které jsou tématem tohoto kratičkého textu. Herci sloužili jen jako němí průvodci, jež divák mohl spatřit na začátku a na konci hry - samotná slova hry zaznívala v průběhu hledání odpovědí v mlhostrojem zakouřeném prostoru z rozmístěných reprobeden. Lze tedy v tomto případě nazvat zhlédnutý tvar scénickým čtením?

Předposlední inscenace festivalu připadla na 25. května. Marika Smreková režírovala text Arne Lygreho Nic ze mě (Ingenting av meg) jako pohyblivý obraz, ve kterém část herců jezdila na kolech, kolečkových bruslích či dokonce jezdících kancelářských židlích - velikost prostor Mosilany takovou koncepci pohodlně dovolila. Všechny pojízdné prostředky směřovaly k tragické automobilové nehodě. $\mathrm{K}$ té dojde na počátku hry, která ukazuje bezmoc slov a prázdnotu reality, jakou kolem sebe člověk konstruuje.

Tečku za brněnským Specifikem udělal 28. května Jan Lepšík a kolektiv HaDivadla při čtení Prohlidky (Visning) Cecilie Løveide. A bylo to vpravdě smutné a neinvenční zakončení festivalu, který, díky dobré volbě texů i inscenačních postupů, v dobrém světle ukázal možnosti norské dramatiky. Přestože tvưrčí tým Prohlidky patřil k těm nejprofesionálnějším (v jiných čteních působili studenti herectví, režie, nebo také úplní amatéři), jeho inscenační úsilí se soustředilo jen na usazení jednotlivých protagonistů hry kolem stolu a př́ležitostných odchodů a příchodů - což byla u hamletovského textu o hořkosladké návštěvě domu na prodej velká škoda. 
Rozpačitý závěr Specifiku 2015 pouká- i návštěvnost festivalu sestupnou tendenci zal na několik organizačních lapsů, které - s Fredrikem Brattbergem už žádná bekvětnovou přehlídku norského dramatu seda neproběhla, byt byl autor př́tomen. provázely. Především se jednalo o malou Kapitolu samu pro sebe pak představuje propagaci festivalu, který kvůli tomu zů- absence sociálních zařízení v celém arestal široké divadelní veřejnosti skrytý - až álu. Ovšem i přes spartánské podmínky na zmínku na webových stránkách a so- zůstává faktem to, že divadlo Feste díky ciální síti bylo těžké dohledat jakékoliv spolupráci s překladatelkami přineslo na informace v médiích apod. První čtení českou půdu šest zcela nových, a tedy zde bylo díky dlouho připravované návštěvě norské dramatičky Vennerød spoluorganizováno společně se sdružením Skandinávský dům, které zajistilo nejen tlumočení a vedení besedy, ale i částečnou propagaci. Poté však měla organizovanost DOI: 10.5817/TY2016-1-22 